\title{
Deformasi Slot Beberapa Produk Braket Stainless Steel Akibat Gaya Torque Pada Kawat Stainless Steel
}

\author{
Atika Zairina*, Erwin Siregar**, dan Nia Ayu Ismaniati** \\ *Program Studi Ortodonsia PPDGS Fakultas Kedokteran Gigi Universitas Indonesia \\ **Bagian Ortodonsia Fakultas Kedokteran Gigi, Universitas Indonesia \\ *JI.Salemba Raya No.4 Jakarta Pusat 10430; e-mail: atika_1709@yahoo.com
}

\begin{abstract}
ABSTRAK
Deformasi slot braket dapat mengurangi besar gaya torque yang akan dihantarkan ke gigi dan jaringan pendukungnya. Beberapa braket stainless steel yang beredar dipasaran belum pernah diteliti kualitasnya dalam perawatan ortodonsi. Tujuan penelitian adalah untuk membandingkan besar gaya torque akibat sudut puntir $30^{\circ}, 45^{\circ}$ kawat stainless steel dan deformasi slot permanen akibat gaya torque tersebut antara kelompok merk braket (3M, Biom, Versadent, Ormco dan Shinye). Penelitian dilakukan pada lima puluh braket stainless steel edgewise dari lima kelompok merk braket $(n=10)$ di lem ke akrilik. Masing-masing braket dilakukan pengukuran tinggi slot dengan mikroskop stereoskopi lalu dipasang ke alat uji torque yang sudah dibuat untuk penelitian ini. Setelah dilakukan uji torque, braket di ukur kembali tinggi slotnya dan dibandingkan dengan pengukuran sebelumnya untuk mengetahui adanya deformasi slot. Hasil analisis statistik menunjukkan perbedaan bermakna besar gaya torque pada sudut puntir $30^{\circ}$ dan $45^{\circ}$ antara Biom dan Shinye dengan Omrco. Gaya torque paling besar yaitu pada merk braket $3 \mathrm{M}\left(30^{\circ}=442,12 \mathrm{gmcm}\right.$ dan $\left.45^{\circ}=567,99 \mathrm{gmcm}\right)$, sedangkan yang terkecil adalah Biom $\left(30^{\circ}=285,50 \mathrm{gmcm}, 45^{\circ}=361,38 \mathrm{gmcm}\right)$. Perbedaan deformasi slot braket terjadi hampir pada semua kelompok merk braket. Deformasi slot braket hanya terjadi pada merk braket Biom $(2,82 \mu \mathrm{m})$ dan Shinye $(2,52 \mu \mathrm{m})$. Kesimpulan, salah satu faktor yang mempengaruhi besar gaya torque dan terjadinya deformasi slot yaitu komposisi dan proses manufaktur dari braket stainless steel. Proses manufaktur yang tidak sesuai standar dapat menyebabkan kualitas braket yang buruk. Deformasi slot permanen dalam penelitian ini terjadi pada merek braket Biom dan Shinye.
\end{abstract}

Maj Ked Gi. Juni 2013; 20(1): 21 - 30

Kata kunci: Deformasi slot, torque, braket, kawat, sainless steel

\begin{abstract}
Slot Deformation of Various Stainless Steel Bracket Due to Torque Expression On The Wire. Bracket slot deformation can reduce the amount of torque that will be transmitted to teeth and supporting tissues. The quality of some stainless steel brackets in the market is still questionable for orthodontic treatments. This research aims to compare the amount of torque expression due to torsion angle of $30^{\circ}$ and $45^{\circ}$ at the stainless steel wire and bracket slot permanent deformation caused by the torque in each examined bracket brands (3M, Biom, Versadent, Ormco and Shinye). Fifty Stainless Steel Edgewise brackets from five different brands $(n=10)$ were attached onto an acrylic. Each bracket slot width was measured with a stereoscopic microscope and then mounted onto a torque apparatus that had been prepared for this study. Once the torque test was done, the width of bracket slot was re-measured to determine if there was a difference from initial bracket slot width at $45^{\circ}$. The results of ANOVA showed significant differences in the amount of torque at torsion angle of $30^{\circ}$ and $45^{\circ}$ between Biom and Shinye with Omrco. The $3 \mathrm{M}$ transmitted the highest load $\left(30^{\circ}=442,12 \mathrm{gmcm}\right.$ and $\left.45^{\circ}=567,99 \mathrm{gmcm}\right)$, while the lowest was of Biom $\left(30^{\circ}=285,50 \mathrm{gmcm}\right.$ and $\left.45^{\circ}=361,38 \mathrm{gmcm}\right)$. Differences in slot bracket deformation were found virtually in all groups of bracket brands. Deformation of bracket slots occurs only in Biom $(2.82 \mu \mathrm{m})$ and Shinye $(2.52 \mu \mathrm{m})$. From the observation, it is concluded that one of the major factors that affect torque and deformation of bracket slot is composition and manufacturing process of the stainless steel brackets. Manufacturing process that does not meet the standard can lead to a poor quality bracket. Permanent slot deformation in this study occurrs with Biom and Shinye bracket brands.

Maj Ked Gi. Juni 2013; 20(1): 21- 30.
\end{abstract}

Key Words: Slot deformation, torque, brackets, wire, Stainless Steel 


\section{PENDAHULUAN}

Kebutuhan perawatan ortodonti di Indonesia meningkat dari berbagai kalangan anak-anak, remaja dan dewasa. ${ }^{1}$ Piranti ortodonti yang beredar di Indonesia di impor dari mancanegara. Pertimbangan dalam memilih piranti ortodonti salah satunya adalah sifat mekanis yang dimiliki, karena berpengaruh terhadap mekanoterapi dan hasil klinis perawatan ortodonti. ${ }^{2,3}$

Braket ortodonti merupakan komponen penting dalam piranti ortodonti cekat karena menghantarkan gaya dari kawat ke struktur gigi dan jaringan pendukungnya sehingga terjadi pergerakkan gigi. 4.5,6 Pergerakkan gigi dalam perawatan ortodonti dihasilkan dari interaksi antara kawat dengan braket dan ditunjang jaringan periodonsium yang sehat. Braket Stainless Steel paling banyak digunakan karena lebih ekonomis, tidak mudah fraktur atau deformasi, tahan korosi dan biokompatibel. ${ }^{7}$

Komposisi logam dan proses manufaktur braket Stainless Steel mempengaruhi sifat fisik dan mekanis, salah satunya kekerasan dan kekuatan. ${ }^{5}$ Beberapa pabrik mengurangi biaya produksi dengan mengabaikan proses manufaktur yang sesuai dengan standarisasi. Hal ini tentu saja merugikan, karena berdampak pada hasil perawatan kurang baik. Jadi, kualitas braket yang baik adalah salah satu syarat untuk dapat menghantarkan gaya yang optimal dan adekuat sehingga menghasilkan pergerakkan gigi yang diinginkan. ${ }^{5,7,8}$

Salah satu jenis pergerakkan gigi dalam perawatan ortodonti adalah torque. Torque adalah perubahan inklinasi labio atau bukopalatal mahkota atau akar gigi. ${ }^{8}$ Gaya torque yang dibutuhkan yaitu 50-200 gramcentimeter $(\mathrm{gmcm})$ untuk gigi insisivus sentral atas dan diperoleh dari aktivasi puntiran kawat di dalam slot braket. Menurut Lacoursiere dkk., ${ }^{9}$ ekspresi torque yang dihasilkan dipengaruhi oleh besarnya puntiran kawat, ukuran dan jenis kawat, komposisi kawat, play yang dibentuk antara kawat dan slot braket, inklinasi gigi, dan resistensi deformasi slot braket. Lacoursiere dkk. ${ }^{9}$ menitikberatkan bahwa deformasi slot braket merupakan faktor yang paling berpengaruh dalam mengurangi ekspresi torque. Kapur dkk. ${ }^{4}$ menemukan bahwa deformasi elastis yang terjadi dapat mengurangi besar gaya torque yang akan dihantarkan kegigi dan jaringan pendukungnya, dan deformasi plastis juga terjadi pada beberapa merk braket Stainless Steel yang diteliti.

Berbagai penelitian di luar negeri yang membandingkan deformasi slot braket akibat gaya torque dari berbagai jenis braket Stainless Steel sudah dilakukan. ${ }^{5.9}$ Namun, penelitian tersebut menggunakan merk braket yang tidak beredar di Indonesia. Oleh karena itu, perlu dilakukan penelitian yang membandingkan besarnya gaya torque yang dihasilkan dan deformasi slot dari berbagai merk braket Stainless Steel yang memang beredar dan digunakan di Indonesia.

Berdasarkan hal tersebut diatas maka penulis ingin mengetahui mengenai besarnya gaya torque yang dihasilkan dan deformasi slot braket dari beberapa merk braket Stainless Steel yang beredar di Indonesia.

\section{METODE PENELITIAN}

Penelitian ini merupakan eksperimental laboratorik yang dilakukan di laboratorium Biomedis Universitas Indonesia, Gedung Pascasarjana Salemba dan PT Surya Sarana DInamika, Bandung pada bulan Maret - April 2013. Sampel yang digunakan yaitu lima kelompok merk braket Stainless Steel Edgewise (tip dan torque $0^{\circ}$ ) slot .022" untuk gigi insisivus sentral atas kanan yaitu kelompok A braket DynaLock edgewise produk $3 \mathrm{M}$ (USA), kelompok $B$ produk Biom (Cina), kelompok $C$ produk Versadent (USA), kelompok D braket Mini Diamond produk Ormco (USA) dan kelompok $E$ produk Shinye (Cina) dengan masing-masing kelompok sebanyak 10 braket. Sampel braket dipasang pada alat uji torque dan kemudian diaplikasikan gaya torque dari kawat Stainless Steel .019x.025" dengan sudut puntir $30^{\circ}$ dan $45^{\circ}$. Deformasi slot braket dilihat melalui mikroskop stereo dengan mengukur perbedaan tinggi slot braket sebelum dan sesudah aplikasi gaya torque.

Penelitian menggunakan alat uji torque yang dirakit sendiri dan telah dikalibrasi di Balai Bahan dan Barang Teknik (B4T) Bandung. Alat uji torque terdiri dari meja translasi untuk pengaturan sampel 


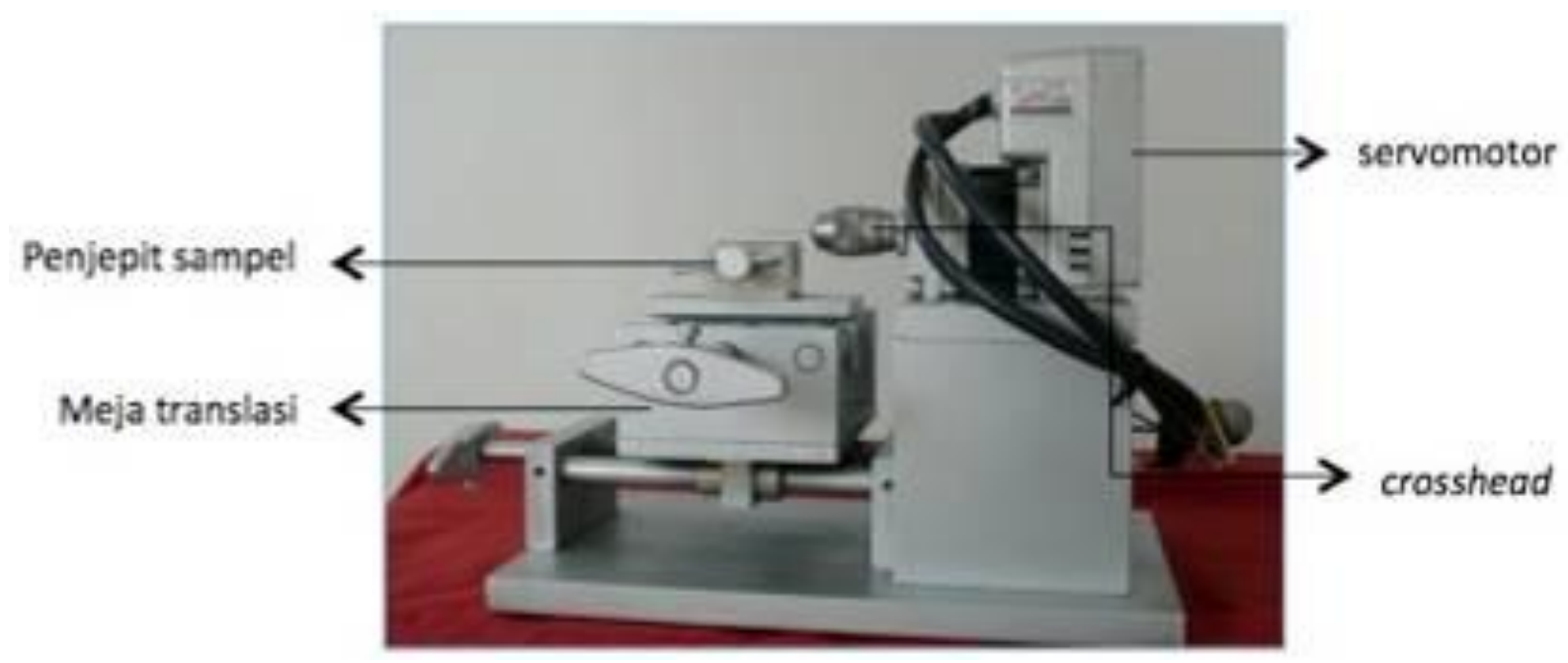

Gambar 1. Alat uji torque dari arah lateral

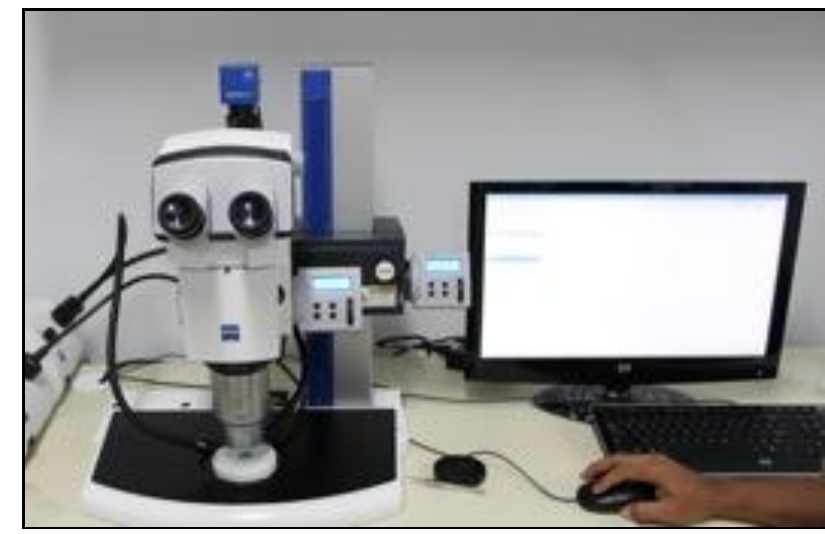

(A)

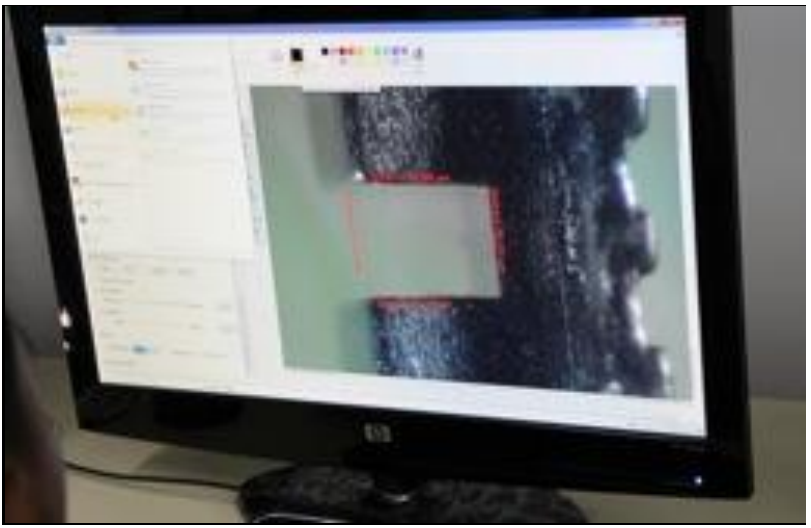

(B)

Gambar 2. (A) Mikroskop stereoskopi Discovery V12 (Carl Zeiss Microimaging GmbH, Jerman) yang tersambung dengan komputer dan AxioCam. (B) Perangkat lunak ZEN lite

braket, penjepit sampel, crosshead, servomotor, chart recorder dan AVO meter (Gambar 1). Servomotor merek Cool Muscle akan memuntir kawat dan chart recorder akan menampilkan besar gaya torque berdasarkan sudut puntir kawat dalam satuan gram sentimeter (gmcm).

Mikroskop stereoskopi yang digunakan yaitu DIscovery V12 yang disambungkan dengan perangkat komputer dan Axiocam (Gambar 2A) dan perangkat lunak Zen lite (Gambar 2B). Tempat peletakan braket yaitu plat akrilik dengan bentuk balok panjang 39 $\mathrm{mm}$, lebar $6 \mathrm{~mm}$ dan tinggi $18 \mathrm{~mm}$, lem loctite 495, kawat Stainless Steel .019x0.025”, karet elastomerik, kuas, pinset braket, alat tulis dan alkohol $70 \%$.

Penelitian ini diawali dengan penelitian pendahuluan dan uji kesesuaian intraobserver dengan uji Bland-Altman. Pemilihan braket dilakukan secara acak untuk menyamarkan identitas braket, dilakukan oleh pihak lain dengan mengetahui kode nomor urut dengan merk braketnya dan di catat dalam buku penelitian. Braket ditempel pada akrilik dengan lem loctite 495 lalu di pasang pada mikroskop stereoskopi untuk dilakukan pengukuran pertama tinggi slot braket. Pengukuran tinggi slot 
braket dilakukan dengan membuat dua garis yaitu garis terluar braket (A) dan garis terdalam braket (B) (Gambar 3). Hasil pengukuran menggunakan rumus $\mathrm{A}+\mathrm{B} / 2$.

Setelah dilakukan pengukuran tinggi slot pertama lalu kawat Stainless Steel .019x0.025" diligasi dengan karet elastomeric ke slot braket. Akrilik dengan sampel braket dipasang ke alat uji torque dengan pengaturan akrilik harus sejajar dengan ujung crosshead dan berjarak $6 \mathrm{~mm}$ dari ujung crosshead ke jarak antara sisi mesial braket lalu dikencangkan. Jarak ini berdasarkan rata-rata jarak antar braket pada gigi insisivus rahang atas (jarak interbraket didalam mulut) (Gambar 4A). Servomotor sebagai penggerak akan memuntir kawat dengan kecepatan rata-rata crosshead 4\% menit yang sudah diprogram ke servomotor dan chart recorder akan menampilkan gaya torque dalam satuan gram sentimeter (gmcm) (Gambar 4B). Setelah dilakukan uji torque, kawat dilepas lalu dilakukan pengukuran tinggi slot yang kedua dengan mikroskop stereo. Deformasi slot braket dilihat dengan membandingkan pengukuran tinggi slot sebelum dan sesudah uji torque.

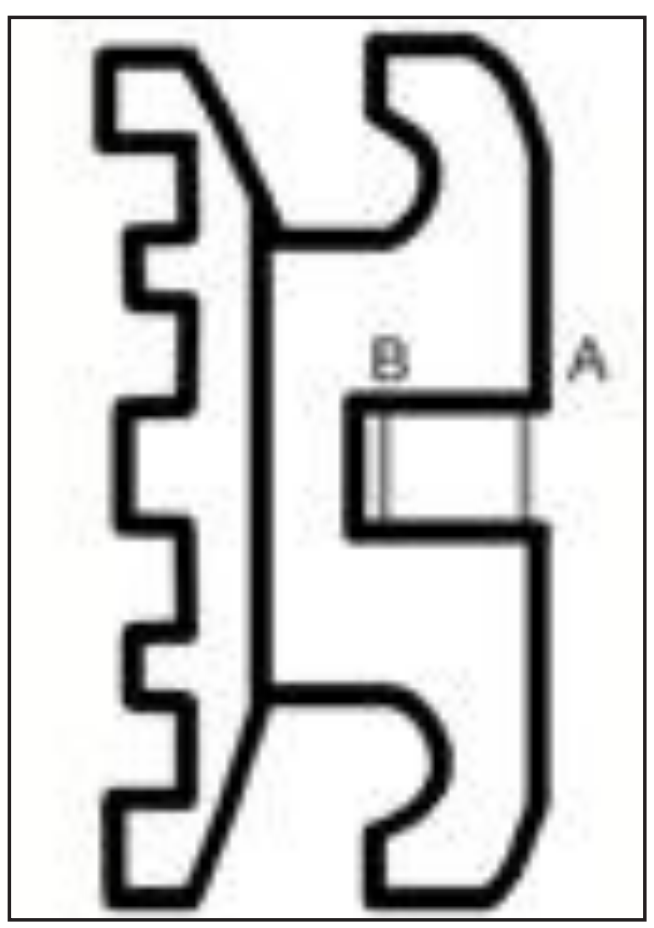

Gambar 3. Pengukuran dari arah lateral dengan menggunakan dua garis yaitu garis A dan garis B. (Sumber : Cash AC, dkk. 2004) ${ }^{13}$
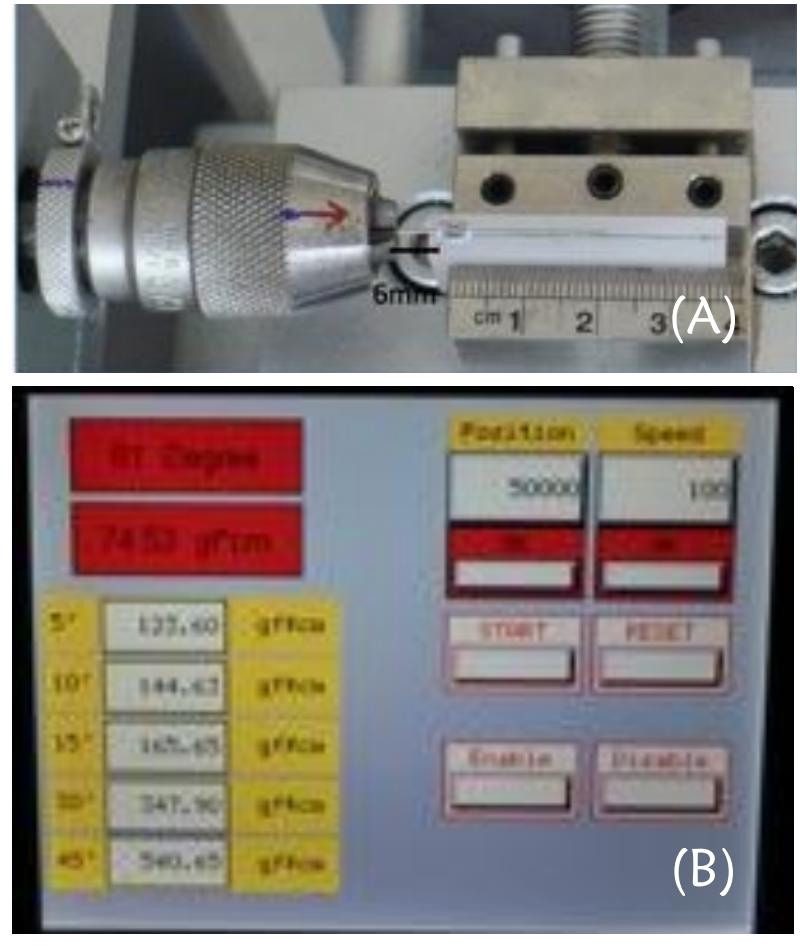

Gambar 4. (A) Peletakan akrilik di alat uji torque. (B) Chart recorder pada servomotor akan menampilkan gaya torque dalam gmcm

\section{HASIL PENELITIAN}

Tabel 1 menunjukkan nilai rerata besar gaya torque kawat Stainless Steel .019x.025" pada braket kelompok A (Dyna-Lock Edegewise 3M), B (Biom), $C$ (Versadent), D (Ormco) dan E (Shinye) dengan sudut puntir $30^{\circ}$ dan $45^{\circ}$ dan perbedaan besar gaya torque antara beberapa kelompok merk braket dengan kelompok D (Ormco) sebagai kelompok pembanding. Besar gaya torque dengan sudut puntir $30^{\circ}$ dan $45^{\circ}$ terbesar pada kelompok A (3M) dan terkecil pada kelompok B (Biom) dan kelompok $\mathrm{E}$ (Shinye).

Uji multivariat untuk sudut puntir $30^{\circ}$ dan $45^{\circ}$ menunjukkan keseluruhan hasil uji dengan nilai $\mathrm{p}<0.05$ maka disimpulkan bahwa paling tidak terdapat dua kelompok yang berbeda. Selanjutnya untuk mengetahui kelompok mana yang berbeda maka dilakukan uji post hoc (Bon ferroni) dengan kelompok pembanding yang standar yaitu kelompok $\mathrm{D}$ (Ormco). Hasil menunjukkan perbedaan bermakna secara statistik $(p<0.001)$ antara Biom - Ormco 
dan Shinye- Ormco pada sudut puntir $30^{\circ}$. Analisa statistik untuk perbedaan gaya torque dengan sudut puntir $45^{\circ}$ terlihat perbedaan bermakna secara statistik $(p<0.001)$ antara $3 \mathrm{M}$ - Ormco, Biom Ormco dan Shinye- Ormco (Tabel 1).

Gambar 5 menunjukkan perbedaan tinggi slot braket sebelum dan sesudah uji torque pada kelompok antar merk braket. Peneliti menetapkan deformasi pada braket terjadi apabila selisih rerata tinggi slot braket sebelum dan sesudah uji torque $>$ $2 \mu \mathrm{m}$. Hal ini sesuai juga dengan penelitian Kapur dkk. ${ }^{4}$

\section{Kel 3M}

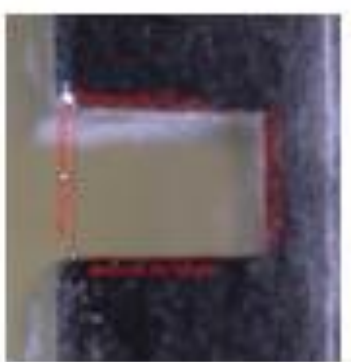

(A) Sebelum

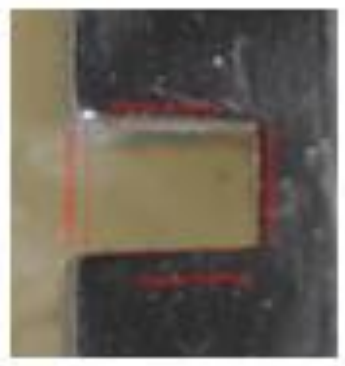

(A) Sesudah

Kel Versadent

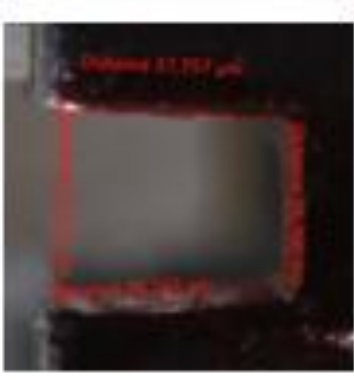

(C) Sebelum

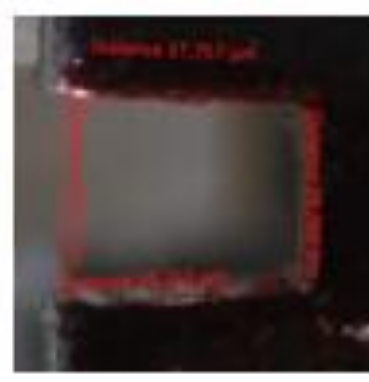

(C) Sesudah
Uji deformasi slot antar kelompok merk braket akibat gaya torque kawat Stainless Steel .019x.025" dengan sudut puntir $45^{\circ}$ digunakan analisis komparatif numerik berpasangan dua kelompok yaitu uji t-test berpasangan. Nilai p secara statistik untuk semua kelompok berbeda bermakna $(p<0,05)$ tetapi secara klinis selisih rerata tinggi slot sebelum dan sesudah aplikasi gaya torque mengalami deformasi permanen apabila ada pelebaran tinggi slot $\geq 2 \mu \mathrm{m}$ yang terdapat pada Biom $(2,82 \mu \mathrm{m})$ dan Shinye $(2,52 \mu \mathrm{m})$ (Tabel 2).

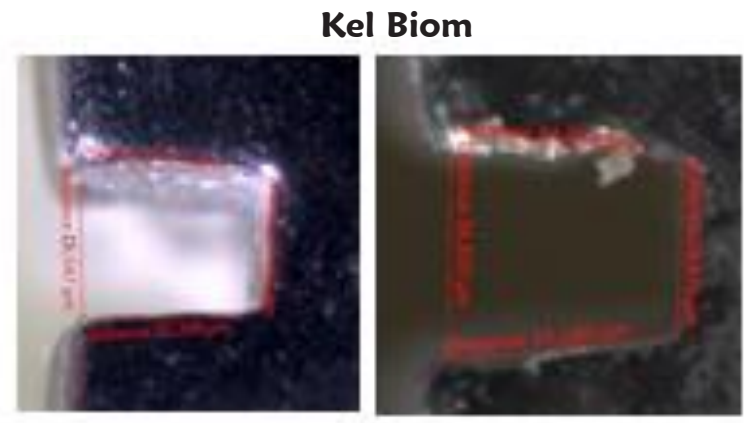

(B) Sebelum

(B) Sesudah

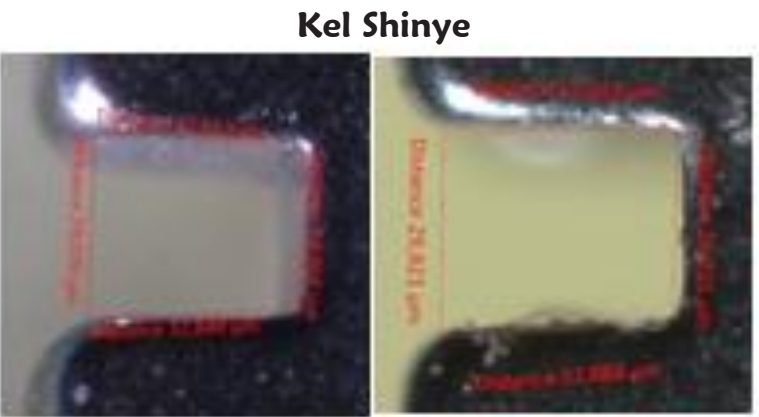

(D) Sebelum

(D) Sesudah

Kel Ormco

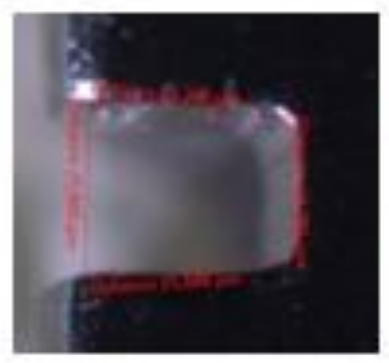

(E) Sebelum

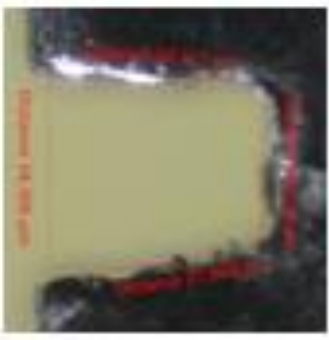

(E) Sesudah

Gambar 5. Foto uji antar braket sebelum dan sesudah pemberian gaya torque kawat Stainless Steel .019x .025 " dengan sudut puntir $45^{\circ}$. Pelebaran slot terlihat jelas pada kelompok merk braket Biom dan Shinye. 
Tabel 1. Hasil pengukuran perbedaan gaya torque kawat Stainless Steel .019x.025" dengan sudut puntir $30^{\circ}$ dan $45^{\circ}$ antara kelompok braket

\begin{tabular}{|c|c|c|c|c|c|c|c|}
\hline & Kel & $\begin{array}{l}\text { Rerata } \\
\text { (gmcm) }\end{array}$ & $\begin{array}{c}\text { SD } \\
(\mathrm{gmcm})\end{array}$ & Nilai $p$ & $\begin{array}{l}\text { Selisih rerata } \\
\qquad(\mathrm{gmcm})\end{array}$ & Min & Maks \\
\hline Sudut puntir & $3 M$ & 442,12 & 36,55 & 0,113 & 25,07 & $-6,16$ & 56,31 \\
\hline \multirow[t]{4}{*}{$30^{\circ}$} & Biom & 279,36 & 35,28 & $<0,001 *$ & $-137,68$ & $-168,92$ & $-106,45$ \\
\hline & Versadent & 393,58 & 22,91 & 0,137 & $-23,47$ & $-54,71$ & 7,76 \\
\hline & Shinye & 285,50 & 35,61 & $<0,001 *$ & $-131,54$ & $-162,78$ & $-100,31$ \\
\hline & Ormco & 417,05 & 40,50 & Pembanding & & & \\
\hline Sudut puntir & $3 M$ & 567,99 & 63,28 & $<0,001 *$ & 67,55 & 32,69 & 102,42 \\
\hline \multirow[t]{4}{*}{$45^{\circ}$} & Biom & 361,48 & 10,11 & $<0,001 *$ & $-138,96$ & $-173,82$ & $-104,09$ \\
\hline & Versadent & 523,93 & 29,83 & 0,181 & 23,49 & $-11,37$ & 58,36 \\
\hline & Shinye & 432,12 & 38,85 & $<0,001 *$ & $-68,32$ & $-103,19$ & 32,69 \\
\hline & Ormco & 500,44 & 31,38 & Pembanding & & & \\
\hline
\end{tabular}

Uji Post-hoc pada generalized linear model (GLM)

*Nilai $\mathrm{p}<0.001$ = terdapat perbedaan bermakna secara statistik dengan kelompok D (pembanding).

Tabel 2. Hasil pengukuran tinggi slot braket sebelum dan sesudah uji torque (deformasi slot braket) pada masing-masing kelompok braket

\begin{tabular}{llcccccc}
\hline \multirow{2}{*}{ Kel } & $\begin{array}{c}\text { Waktu } \\
\text { pengukuran }\end{array}$ & $\begin{array}{c}\text { Rerata tinggi slot } \\
\text { braket }(\mu \mathrm{m})\end{array}$ & $\begin{array}{c}\text { SD } \\
(\mu \mathrm{m})\end{array}$ & $\begin{array}{c}\text { Selisih rerata } \\
(\mu \mathrm{m})\end{array}$ & Min & Maks & Nilai p \\
\hline \multirow{2}{*}{$3 \mathrm{M}$} & Sebelum & 29,49 & 0,32 & $-0,54$ & $-0,86$ & $-0,22$ & $0,004^{*}$ \\
\multirow{3}{*}{ Biom } & Sesudah & 30,03 & 0,48 & & & & \\
& Sebelum & 27,87 & 1,13 & $-2,82$ & $-3,36$ & $-2,28$ & $<0,001 * *$ \\
\multirow{2}{*}{ Versadent } & Sesudah & 30,69 & 0,90 & & & & \\
& Sebelum & 28,36 & 1,07 & $-1,23$ & $-1,55$ & $-0,91$ & $<0,001 * *$ \\
\multirow{2}{*}{ Shinye } & Sesudah & 29,59 & 1,15 & & & & \\
& Sebelum & 27,50 & 0,51 & $-2,52$ & $-3,93$ & $-1,11$ & $0,003 *$ \\
\multirow{2}{*}{ Ormco } & Sesudah & 30,02 & 1,81 & & & & \\
& Sebelum & 27,84 & 0,50 & $-0,54$ & $-0,73$ & $-0,34$ & $<0,001 * *$ \\
& Sesudah & 28,38 & 0,57 & & & & \\
\hline
\end{tabular}

\section{Uji t berpasangan}

* Nilai $p<0.05$ = terdapat perbedaan bermakna secara statistik, tetapi secara klinis selisih rerata yang bermkana adalah $>2 \mu \mathrm{m}$.

**Nilai $p<0.0001$ = terdapat perbedaan bermakna secara statistik, tetapi secara klinis selisih rerata yang bermkana adalah $>2 \mu \mathrm{m}$. 
Tabel 3. Hasil pengukuran perbedaan deformasi deformasi slot braket antara kelompok merk braket akibat gaya torque kawat Stainless Steel .019x.025" dengan sudut puntir $45^{\circ}$

\begin{tabular}{lcccccc}
\hline Kel & Rerata $(\mu \mathrm{m})$ & SD $(\mu \mathrm{m})$ & Median & Min & Maks & Nilai $\mathrm{p}$ \\
\hline $3 \mathrm{M}$ & 0,54 & 0,45 & 0,34 & 0,14 & 1,39 & $<0,001^{*}$ \\
Biom & 2,82 & 0,76 & 2,87 & 1,65 & 4,19 & \\
Versadent & 1,23 & 0,45 & 1,24 & 0,56 & 1,89 & \\
Ormco & 0,54 & 0,27 & 0,43 & 0,30 & 1,12 & \\
Shinye & 2,52 & 1,97 & 1,76 & 0,52 & 6,17 & \\
\hline
\end{tabular}

Uji Kruskal Wallis

* Nilai $p<0.001=$ terdapat perbedaan bermakna secara statistik ,

Tabel 4. Analisis post-hoc untuk perbedaan deformasi slot braket antara kelompok A,B,C,D,E akibat gaya torque kawat Stainless Steel .019x.025" dengan sudut puntir $45^{\circ}$

\begin{tabular}{|c|c|c|c|c|}
\hline & Biom & Versadent & Shinye & Ormco \\
\hline $3 M$ & $<0,001 * *$ & $0,008 *$ & $0,001 *$ & 0,326 \\
\hline Biom & & $<0,001 * *$ & 0,290 & $<0,001 * *$ \\
\hline Versadent & & & 0,151 & $0,001 *$ \\
\hline Shinye & & & & $0,001 *$ \\
\hline
\end{tabular}

\section{Uji Mann-Whitney}

* $\quad$ Nilai $p<0.05=$ terdapat perbedaan bermakna secara statistik

** $\quad$ Nilai $p<0.0001=$ terdapat perbedaan bermakna secara statistic

Perbedaan deformasi slot braket antara kelompok merk braket akibat gaya torque kawat Stainless Steel .019x.025" dengan sudut puntir $45^{\circ}$ di analisa dengan uji Kruskal Wallis dan diperoleh nilai $p<0.001$ sehingga disimpulkan ada perbedaan bermakna secara statistik deformasi slot antara beberapa kelompok merk braket (Tabel 3).

Selanjutnya, untuk mengetahui kelompok mana yang berbeda maka dilakukan post hoc dengan uji Mann-Whitney (Tabel 4). Nilai p pada tabel analisa post-hoc yaitu ada perbedaan bermakna antara beberapa kelompok braket kecuali antara merk braket $3 \mathrm{M}$ dengan Ormco, Biom dengan Shinye dan Versadent dengan kelompok Shinye.

\section{PEMBAHASAN}

Besar gaya torque paling besar pada sudut puntir $30^{\circ}$ dan $45^{\circ}$ yaitu braket $3 \mathrm{M}$, urutan kedua yaitu Ormco dan ketiga adalah Versadent. Versadent menunjukkan besar gaya torque lebih besar daripada Ormco pada sudut puntir $45^{\circ}$ (Tabel 1). Sedangkan, urutan yang keempat adalah Shinye dan paling terakhir yaitu Biom. Besar gaya torque yang dihasilkan dipengaruhi dari faktor kawat, braket dan morfologi gigi. Menurut Kapur, ${ }^{10}$ faktor braket yaitu bahan material, proses manufaktur, desain, ukuran slot, bentuk slot, metode ligasi dan terjadinya deformasi permanen slot braket saat aplikasi gaya. Pada penelitian ini metode ligasi menggunakan 


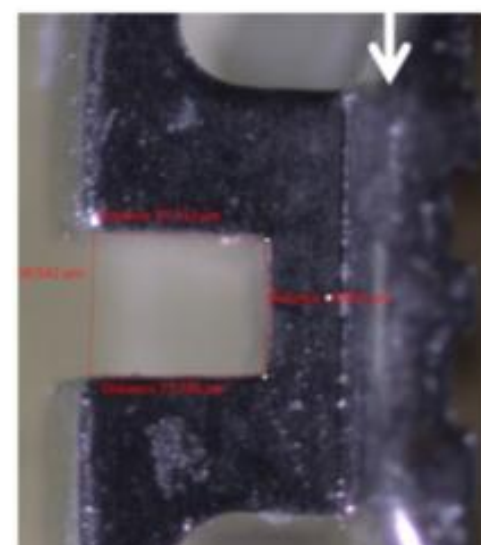

(A) Braket $3 \mathrm{M}$

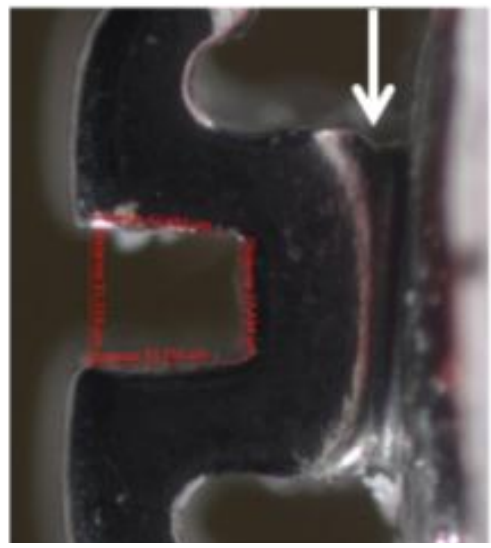

(B) Braket Biom

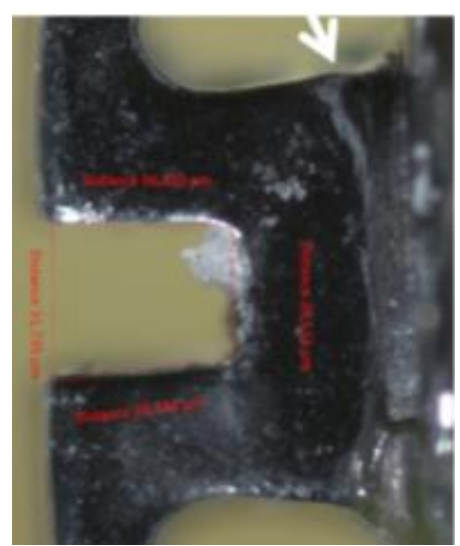

(C) Braket Shinye

Gambar 6. Foto mikroskop stereo (A) Braket 3M, (B) Braket Biom, (C) Braket Shinye. Tanda panah menunjukkan area persambungan antar komponen sayap dengan dasar braket. Braket Biom dan Shinye terlihat area persambungan melalui proses brazing

modul elastomerik karena menurut Flores $\mathrm{dkk}^{5}$ ligasi dengan kawat ligatur atau modul elastomerik tidak berefek terhadap terjadinya deformasi permanen braket Stainless Steel.

Dari penelitian ini besar gaya torque pada semua kelompok braket melebihi dari gaya torque yang dibutuhkan secara klinis terutama pada sudut puntir $45^{\circ}$. Kelompok merk braket $3 \mathrm{M}$ pada sudut puntir $45^{\circ}$ menghasilkan gaya torque paling besar yaitu > $500 \mathrm{gmcm}$. Hal ini sesuai dengan penelitian eksperimental yang dilakukan oleh Lacoursiere $\mathrm{dkk}^{9}$ bahwa gaya torque dalam penelitian tersebut mencapai $900 \mathrm{gmcm}$ dengan sudut puntir $51^{\circ}$. Beliau menjelaskan bahwa dalam praktik sehari-hari aplikasi gaya torque pada kawat biasanya hanya sebesar $20^{\circ}$ dan dilakukan sebelum kawat dimasukkan ke dalam slot braket. Saat dimasukan ke slot braket terjadi aktivasi regangan/torsion pada kawat sehingga sudut puntir kawat akan bertambah. ${ }^{9}$ Oleh karena itu, dalam penelitian eksperimen laboratorik ini sudut puntir yang digunakan sampai $45^{\circ}$ untuk menyamakan kondisi klinis.

Walaupun dalam penelitian ini semua merk braket menghasilkan gaya torque awal yang sesuai, tetapi apabila terjadi deformasi slot permanen maka gaya yang akan dihantarkan semakin berkurang dan pergerakkan gigi terhambat. Menurut Lacoursiere dkk., ${ }^{9}$ deformasi slot braket merupakan penyebab kehilangan ekspresi torque. Penelitian ini menyimpulkan bahwa ada perbedaan deformasi slot braket hampir pada semua merk braket kecuali antara braket $3 \mathrm{M}$ - Ormco, Biom - Shinye dan Versadent - Shinye (Tabel 4). Braket $3 \mathrm{M}$ dan Ormco masing-masing menunjukkan selisih tinggi slot braket sebelum dan sesudah aplikasi gaya torque yaitu 0,54 $\mu \mathrm{m}$ sehingga secara klinis tidak terjadi deformasi slot braket permanen. Sedangkan, pada braket Biom dan Shinye terjadi selisih tinggi slot sebelum dan sesudah aplikasi gaya torque pada masing-masing kelompok yaitu $2,82 \mu \mathrm{m}$ dan $2,52 \mu \mathrm{m}$ sehingga secara klinis terjadi deformasi slot braket permanen.

Beberapa hal yang dapat menyebabkan deformasi permanen yaitu bentuk geometri slot divergen dengan sudut/tepi slot membulat, komposisi logam dan proses manufaktur braket tidak sesuai dengan standarisasi. Proses manufaktur untuk braket 3M, Ormco dan Versadent dari data spesifikasi yang diperoleh yaitu MIM (Metal Injection Molding), sedangkan untuk braket Biom dan Shinye dari hasil foto dengan pemeriksaan mikroskopi stereo terlihat sambungan dua logam dengan logam pengisi antara komponen sayap dengan dasar braket pada braket Biom dan Shinye sehingga kemungkinan proses manufaktur kedua merk braket tersebut melalui proses brazing (Gambar 6). Menurut Eliades $\mathrm{dkk}^{11}$, berbagai bahan dasar brazing yang digunakan 
dengan Stainless Steel tidak menghasilkan kualitas braket yang ideal dan bersifat korosif sehingga rentan terjadinya deformasi permanen slot braket.

Hasil gambar mikroskop stereo terlihat bentuk slot untuk braket $3 \mathrm{M}$, Versadent dan Ormco lebih persegi, sudut tajam dan dinding slot atas dan bawah sejajar, sedangkan pada braket Biom dan
Shinye bentuk slot lebih divergen/melebar kearah luar, sudut membulat dan dinding slot atas dan bawah tidak sejajar (Gambar 7). Menurut Cash dkk. dan Kapur, ${ }^{12,13}$ bentuk slot yang divergen dengan sudut/tepi slot membulat dapat mengurangi gaya torque yang dihasilkan karena area kontak antara slot dengan kawat berkurang.

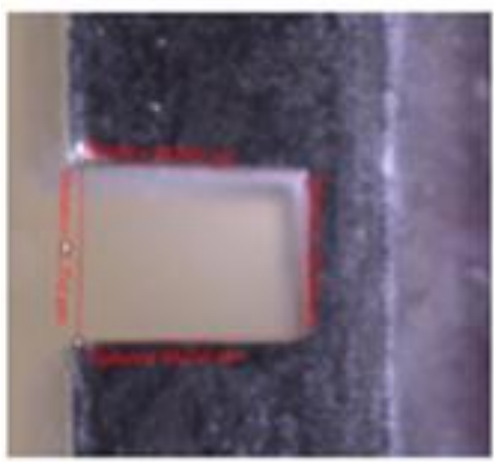

Braket Kelompok

Ormco

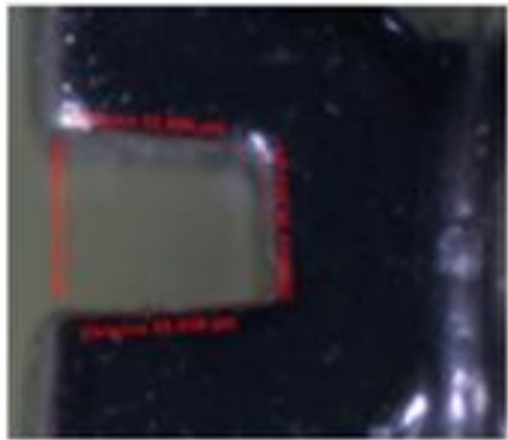

Braket Kelompok

Bion

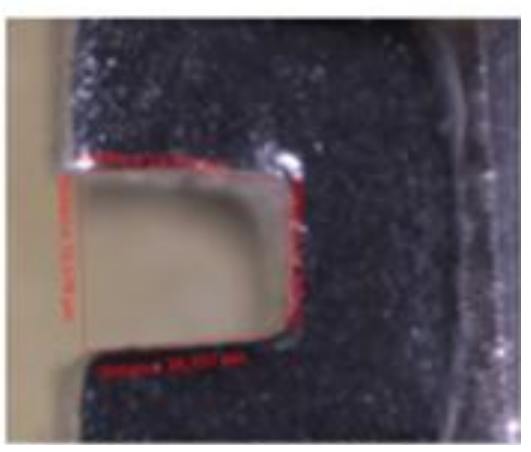

Braket Kelompok

Versadent

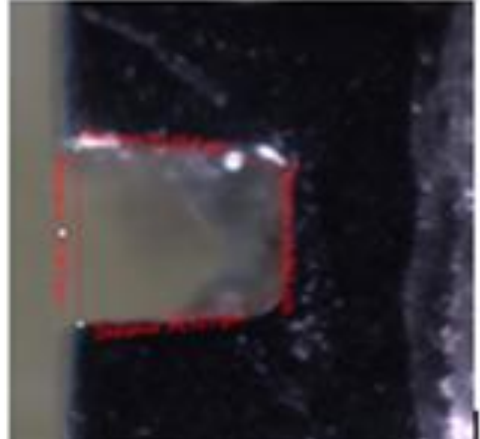

Braket Kelompok D

$3 \mathrm{M}$

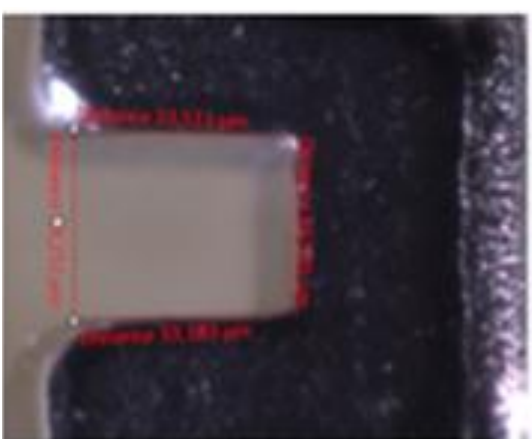

Braket Kelompok E

Shinye

Gambar 7. Foto mikroskop strereo antara kelompok merk braket menunjukkan perbedaan bentuk slot braket dan sudut dasar slot braket. 


\section{KESIMPULAN}

Hasil penelitian ini menunjukkan bahwa besar gaya torque yang paling besar pada sudut puntir $30^{\circ}$ dan $45^{\circ}$ yaitu pada kelompok A braket DynaLock edgewise produk $3 \mathrm{M}$ (USA), urutan kedua dan ketiga yaitu kelompok $D$ braket Mini Diamond produk Ormco (USA) dan kelompok C (Versadent). Sedangkan, urutan keempat yaitu kelompok $\mathrm{E}$ (Shinye) dan gaya torque yang paling kecil yaitu pada kelompok B (Biom). Deformasi slot permanen secara statistik dan klinis terdapat perbedaan yang bermakna pada braket Biom dan Shinye terhadap merk braket lainnya. Deformasi slot permanen disimpulkan terjadi pada merk braket Biom dan Shinye

Manfaat penelitian ini yaitu memberikan gambaran dan informasi bagi ortodontis dan masyarakat mengenai perbedaan kualitas beberapa merk braket Stainless Steel khususnya dalam menghantarkan gaya torque dan terjadinya deformasi slot permanen. Hasil penelitian diharapkan menjadi salah satu dasar untuk kontrol kualitas braket yang beredar di Indonesia sehingga efektivitas dan keamanan pasien lebih terjamin.

\section{DAFTAR PUSTAKA}

1. Foster TD. Buku ajar ortodonsi. Edisi 3. Jakarta: EGC; 1993. H. 311-20.

2. Anusavice KJ. Phillips's science of dental material. Ed 11. St.Louis: Saunders; 2003. H. 73-88, 637-9.

3. Brantley WA, Eliades T. Orthodontic materials. Ed 1. Stuttgart-New York: Thieme; 2001. H. 160-7.
4. Kapur R, Sinha PK, Nanda RS. Comparison of load transmission and bracket deformation between titanium and stainless steel bracket. Am J Orthod Dentofacial Orthop. 1999;116: 275-8.

5. Flores DA et al. Deformation of metal brackets: a comparative study. Angle Orthod. 1994; 64(4): 283-90.

6. Sriram G, Krishnaswamy NR. Evaluation of elastic deformation in stainless steel and titanium bracket - a comparative study using finite element method (FEM). 2011; 2(4): 308-12.

7. Oh KT, Choo SU, Kim KM, Kim KN. A stainless steel bracket for orthodontic application. Eur J Orthod. 2005; 27: 237-44.

8. Thurow RC. Edgewise orthodontics. Ed 3. St.Louis: Mosby; 1972. 22-9, 35-7, 45-8, 60-2.

9. Lacoursiere RA et al. Measurement of orthodontic bracket tie wing elastic and plastic deformation by arch wire torque expression utilizing an optical image correlation technique. J of Dent Biomechanics. 2010; 1-7.

10. Kapur R. Physical and mechanical properties affecting torque control. J Clin Orthod. 2004; 38(6): 335-40.

11. Eliades $G$, Eliades T, Branley WA, Watts DC. Dental materials in vivo: aging and related phenomena. Ed 1. New York: Quintessence Publishing; 2003: 13945.

12. Kapur R. Physical and mechanical properties affecting torque control. J Clin Orthod. 2004; 38(6): 335-40.

13. Cash AC, Good SA, Curtis RV, McDonald F. An evaluation of slot size in orthodontic brackets-are standards as expected. Angle Orthod. 2004; 74 : 450-3. 